\title{
EFFICIENCY OF APPLICATION \\ OF PLANT GROWTH REGULATORS \\ ON DIFFERENT GENOTYPES OF SUNFLOWER
}

\section{Dmytro Chuyko ${ }^{1}$ \\ Oleksandr Bragin ${ }^{2}$}

DOI: https://doi.org/10.30525/978-9934-26-077-3-29

Abstract. Sunflower is the most common crop in Ukraine. In terms of sunflower seed growing, our country is among the top three world leaders. The aim of the article is to study the possibility of increasing the productivity and improving the seed characteristics of sunflower seeds, the influence of growth regulators on the morphological characteristics of the studied lines, experimental hybrids, varieties and the possibility of improving traditional cultivation technologies. In the process of performing scientific work, introductory, special and general scientific research methods were used. The scientific novelty of the research is aimed at improving and enhancing the productive characteristics and economically useful traits of sunflower lines and hybrids, as well as assessing the feasibility of using growth regulators Fulvital Plus, Ecostim and Quadrostim on these genotypes and their individual reactions. Weather conditions in the period 2018-2020 were unstable and depended on the year. There was a significant impact of PGR on the formation of productivity (increase in the range of $0.7-38.1 \%$ compared to control). The greatest positive impact was achieved on lines Skh808A and Skh1002A. These lines are characterized by high drought resistance and adaptability to adverse conditions in general and major diseases. High rates of PGR impact on experimental hybrids can be justified by the presence of heterosis, which in turn increases the number of dominant alleles in the plant, which help plants better adapt to environmental conditions. PGR had almost no effect on the studied sunflower cultivars, except for the Lakomka cultivar (productivity varied in the range of 82.4-50.9 g, compared to the

\footnotetext{
${ }^{1}$ Postgraduate Student at the Department of Genetics, Breeding and Seed Growing, Kharkiv National Agrarian University named after V.V. Dokuchaev, Ukraine

${ }^{2}$ Candidate of Agricultural Sciences,

Associate Professor at the Department of Genetics, Breeding and Seed Growing, Kharkiv National Agrarian University named after V.V. Dokuchaev, Ukraine
} 
control of $75.9 \mathrm{~g}$ ). The slight effect of PGR on sunflower varieties may explain their inconsistency in the onset of developed phases, the period of onset of a certain phase in the population can vary from a few days to a week. The use of PGR Quadrostim was effective on experimental hybrids, except for the linear-varietal hybrid Skh808A $\times$ Shchelkunchyk, the oil content varied within the control over the years of research $50.8 \%$ (control $20.7 \%$ ). The influence of the studied PGRs on the oil content in the seeds of self-pollinating sunflower lines was specific and varied depending on the genotype of the line and PGR. The practical value of the work is determined by the importance of its end results, both for seed production, breeding practice and for production. The influence of the studied PGRs had an individual nature of influence and varied depending on the genotype of the line, growth regulator and weather conditions surrounding the plants at the time of treatment and subsequent vegetation.

\section{Introduction}

Today, with the help of scientific advances in the world, a significant number of synthetic and natural plant growth regulators have been created. This group of drugs is able to reduce the negative impact of the environment, strengthen the immunity of plants after treatment and allows them to realize their potential productivity.

In order to provide the sown areas of sunflower with high-quality sowing material in sufficient quantities, it is necessary to develop and improve the generally accepted seed production technologies. The main problem is the low performance of lines - components of hybrids. Self-pollinating lines have a pronounced manifestation of incucht depression, so they are often very vulnerable in terms of adaptive properties of plants to sudden and stressful changes in the environment.

The success of heterosis selection of sunflower depends on the availability of source material with a certain set of qualities and its donor properties. Creation of varieties with certain qualities is possible on the basis of knowledge of the laws of inheritance of valuable economic traits in the first hybrid generation. It is important to choose the right parental components for the heterosis combination.

A promising direction to increase the productivity of self-pollinating lines is the use of plant growth regulators (hereinafter - PGR). Among 
the main features of PGR is their ability to increase yields, adaptability of plants to adverse weather conditions, pests and regulate plant development. With the rapid increase in the number of PGRs in the State Register of Pesticides and Agrochemicals, their effect on different types of genotypes and their functionality under uncontrolled weather conditions remains poorly understood.

\section{Analysis of recent research and publications}

In Ukraine, the production of sunflower seeds is one of the main directions of agricultural development to ensure food and economic security of the country. Oil sunflower created at the beginning of the XX century by Ukrainian breeders [1, p. 379; 2, p. 139] today, according to USAD, ranks fourth in the structure of oil production in the world (palm $34 \%$, soybean $29 \%$, rapeseed $15 \%$, sunflower $9 \%$, other oils $13 \%$ ).

Analysis of the data shows that the production of oilseeds in Ukraine over the past two decades has increased by more than four [3, p. 183]. Thus, in 2020 the sown area of sunflower in Ukraine was - 6383.3 thousand/ ha (584.7 thousand/ha - Kharkiv region), compared to 2018 , the total area was -6058.2 thousand/ha (513.5 thousand/ha - Kharkiv region), for comparison with 2010, the sown area of sunflower increased 1.4 times (4417.5 thousand/ha) [4]. The sown area of sunflower in the European Union in 2020 was 4.5 million/ha. The top five in terms of sown areas are Romania 1.2 million/ha, Bulgaria -810 thousand/ha, France -775 thousand/ha, Spain -651 thousand/ha and Hungary 617 thousand/ha [5, p. 14; 6].

The lines that were involved in the research are included in the State Register of plant varieties suitable for distribution in Ukraine and are the parent components of modern hybrids grown in Ukraine [7, p. 237]. Thus, as the cultivation of traditional varieties of oil sunflower in Ukraine is not profitable, the research involved varieties of confectionery direction with different maturity [1, p. 417]. Today the confectionery direction of sunflower use is actively developing in Ukraine, sown areas under varieties of confectionery type of sunflower are about $5 \%$ of the total area $[8$, p. 236; 9, p. 285].

One of the most cost-effective is the use of PGR. To date, a number of synthetic growth regulators have been created, which contain the active substance, which is represented by substances of humic origin (fulvic acids, 
humates), bacterial (extracts from ginseng roots, sea buckthorn, etc.) and PGR, which are based on minerals. (eg succinic acid) [10; 11, p. 33].

The effectiveness of plant growth regulators has been proven by many practical studies, which show a tendency to increase yields, seed quality, resistance of sunflower plants to pests and improve plant adaptability to environmental conditions [12, p. 173; 13, p. 127; 14, p. 138].

However, the problem of PGR application is their dependence on environmental weather conditions, such as soil and air humidity, air and soil temperature on the day of treatment and for a week after it. Depending on these factors, the impact of PGR may be significantly reduced or not occur at all if the plants are under stress $[15 ; 16$, p. 114; 17, p. 216].

Growth regulators are all substances that affect the activity of essential phytohormones contained in the plant. Such substances include all antihibberellins such as, for example, chloromequat chloride, trinexapat ethyl, triazoles and ethephon, the mechanism of action of which is the release of ethylene into the intercellular space. Etefon and trinexpak ethyl are substances widely used in intensive plant cultivation and as protection of plants from lodging (Bragg et al. 1984) [18, p. 260; 19, p. 818].

The effectiveness of the use of drugs containing succinic acid (Treptolem) or the products of life of fungi-micromycetes (Radostim) on seed crops of sunflower was confirmed in studies by the Institute of Plant Breeding V. Ya. Yurieva NAAS of Ukraine [20, p. 24]. According to the results of their research, it was found that the use of these drugs during seed treatment increases the field germination of seeds up to $17 \%$, and sowing qualities increase by an average of $2 \%$. Evidence of the influence of phytohormones of auxin and cytokinin nature.

The use of preparations containing humic substances such as fulvic acids and potassium lignohumate can increase the plant's absorption of trace elements from the soil $[21$, p. 63], to improve the quality and productivity of seeds [22, p. 1559]. Current data suggest that the biostimulating effect of humic substances is characterized by both structural and physiological changes in roots and shoots associated with the absorption, assimilation and distribution of nutrients (indicators of nutrient efficiency).

Today, the world uses growth regulators of synthetic and natural origin. The natural ones include the use of different strains of fungi, extracts from leaves or other vegetative organs of the plant, different types of bacteria, 
and others. The use of strains of Trichoderma spp. in studies [23, p. 85] on lettuce plants (Latuca sativa L.) increased the dry weight of the plant to $26 \%$, it was also noted that some strains of Trichoderma spp. slowed the germination and development of seeds. Treatment of plants with bacterial preparations based on rhizobacterial strains (PGR), actively promotes the development of vegetative mass of the plant and generally improves its productive characteristics [24, p. 5]. Bernard et al., (1997) [25, p. 354] cite the principles of genetic manipulation of bacteria that promote plant growth to enhance the biocontrol of phytopathogens.

The influence of growth regulators of humic origin (Vermimag and Vermiodis) effectively affects the yield of sunflower in the Forest-Steppe conducted by V. M. Sendetsky, O. S. Gorash [26, p. 53; 27, p. 11], L. A. Pokoptseva [28, p. 127] investigated the use of plant growth regulators for pre-sowing treatment of sunflower seeds of Armada hybrid, found that the inlay of sunflower seeds with products of biotechnological cultivation of epiphytic fungi (Emistim C) stimulates germination, which indicates an increase in field germination by $1.5-4.8 \%$. according to control. The use of PGR contributes to the thickening of the stems of sunflower plants by $7-18 \%$, increasing productivity from the basket to $20 \%$.

According to the results of research Y. I. Tkalich [29, p. 124] found that improving the nutritional conditions of sunflower by using for inoculation bacterial drugs Diazofit, KL-9, Diazofit+Phosphointerrin and growth regulator Vimpel in the phase of 3-4 pairs of leaves provides an increase in the main indicators of photosynthetic activity and yield of sunflower.

\section{Research methodology}

In the period 2018-2020 in the research field of the Department of Genetics, Breeding and Seed Growing of Kharkiv National Agrarian University named after V. V. Dokuchaev conducted a study to increase seed productivity of parental lines, experimental hybrids and varieties of sunflower by using growth regulators Fulvital Plus, Ecostim and Quadrostim. The studied drugs were used by spraying during the growing season during the development of 2-5 true leaves and retreatment in the phase of star formation.

Fulvital (preparative form (p. f.) - powder) $150 \mathrm{~g} / \mathrm{ha}$, water-soluble preparation, which includes: salts of fulvic acids, trace elements, organically bound sulfur of natural origin in easily digestible form for plants. 
Ecostim (p.f. - aqueous suspension solution) $25 \mathrm{ml} / \mathrm{ha}$, the active substance is an aqueous-alcoholic solution of metabolites of the symbiotic endophyte fungus strain Panax Ginseng $M$. isolated from ginseng roots.

Quadrostim (p.f. - aqueous suspension solution) $300 \mathrm{ml} / \mathrm{ha}$, which includes four groups of compounds of organic origin: polyethylene oxide (400 and 1500), arachidonic, succinic acid and potassium lignohumate.

For the study used 11 self-pollinated lines of sunflower selection of the Institute of Plant Breeding V. Ya. Yurieva and KhNAU named after V. V. Dokuchaev. The inoculum is represented by sterile analogues Skh808A, Skh808A/Kh1002B, Skh1010A, Skh1012A, Skh1002A with pollen sterility fixers - Kh1010B, Kh1012B, and pollen fertility restorers lines - Kh06135V, Kh06134V, Kh785V. Varieties of confectionery type: Shchelkunchik, Lakomka, Lyuks, Dons'kyy Krupnoplidnyy and oil type variety Myr. Experimental hybrids are based on the above-mentioned self-pollinating lines. Five experimental hybrids with the largest number of seeds were selected from combination crosses - Skh1002A $\times$ Kh1012B, Skh1012A $\times$ Kh06135V, Skh808A $\times$ Kh1002B $\times$ Kh06135V; Skh808A $\times$ Kh1002V $\times$ Kh785V and Skh808A $\times$ Shchelkunchik.

The placement of variants in the experiment is systematic, the repetition is fourfold, according to the method of field experiment [30, p. 16], plot area $16.8 \mathrm{~m}^{2}$, sowing scheme $70 \times 25 \mathrm{~cm}$, predecessor of winter wheat. All lines and experimental hybrids were treated with PGR in the development phase of 2-5 true leaves and subsequent processing was performed in the "star" phase. The treatment was performed in the morning, when the air temperature fluctuates within $+8 \ldots+20^{\circ} \mathrm{C}$. During this period, the plants are covered with morning dew.

During the growing season, phenological observations of the duration of phenological phases and plant measurements were performed. Morphological features were assessed 1-2 weeks before maturity. In the nursery tests were measured 10 plants on the site on the following indicators: total height, diameter of the basket, the total number of leaves. Under laboratory conditions, the weight of 1000 seeds, husk, plant productivity were determined as the average of the combined threshing of baskets of 10 plants on the site. After field and laboratory evaluations, analysis of the obtained results, the best varieties, hybrids, which were determined by valuable economic indicators, were evaluated for oil content. Statistical 
processing was performed according to the standard method of using Microsoft Office Excel 2010 and Gnumerik [31, p. 59].

\section{Agro-climatic conditions of the study}

In general, soil and climatic conditions of the zone of the left-bank Forest-Steppe of Ukraine are favorable for sunflower cultivation. Weather conditions during the study were formed as follows.

In 2018 , there were conditions characterized by a lack of precipitation throughout the growing season and air temperatures above the average long-term temperature.

May 2018 was characterized by the lowest precipitation rates $(15.9 \mathrm{~mm})$ for all years of research with a long-term average $(43.7 \mathrm{~mm})$. The air temperature was $20.8^{\circ} \mathrm{C}$, which is $4.6^{\circ} \mathrm{C}$ higher than the long-term average. In June, the highest amount of precipitation $(43.5 \mathrm{~mm})$ fell during the growing season in the current year, with an average long-term average of $65.7 \mathrm{~mm}$. The air temperature was $21.6^{\circ} \mathrm{C}$, with a normal long-term norm of $19.9^{\circ} \mathrm{C}$. July was characterized by an increase in temperature by $1.8^{\circ} \mathrm{C}$ compared to the average long-term, and torrential rains during which $28.7 \mathrm{~mm}$ of precipitation fell, which is less than half of the average longterm norm (65.5 mm) (Figure 1).

The temperature in August was high $\left(24.6^{\circ} \mathrm{C}\right)$, compared to the longterm average of $20.5^{\circ} \mathrm{C}$. Also, this month there was a severe drought with no precipitation $(0 \mathrm{~mm})$, with a normal long-term average of $51 \mathrm{~mm}$. September was hot, the air temperature exceeded the average long-term indicators by $6.5^{\circ} \mathrm{C}$, and the amount of precipitation was excessively low $(10.7 \mathrm{~mm})$, with the average long-term norm of $45.4 \mathrm{~mm}$.

In 2019, favorable weather conditions developed in May, characterized by a sufficient amount of precipitation $(43.4 \mathrm{~mm})$, with an average longterm average of $43.7 \mathrm{~mm}$. The average temperature $\left(18.4^{\circ} \mathrm{C}\right)$ of air exceeded the average long-term temperature by $2.2^{\circ} \mathrm{C}$. In June, only $23.1 \%$ of the precipitation fell, which is $50.5 \mathrm{~mm}$ less than the long-term average. The average daily air temperature $\left(24.8^{\circ} \mathrm{C}\right)$ was the highest recorded in general for the years of research and exceeded the long-term average by $4.9^{\circ} \mathrm{C}$. July was characterized by average daily temperatures typical for this month, which exceeded the long-term average by only $0.2^{\circ} \mathrm{C}$. Precipitation was $59.2 \%$ compared to long-term averages $(65.5 \mathrm{~mm})$ (Figure 2$)$. 
Chapter «Agricultural sciences»

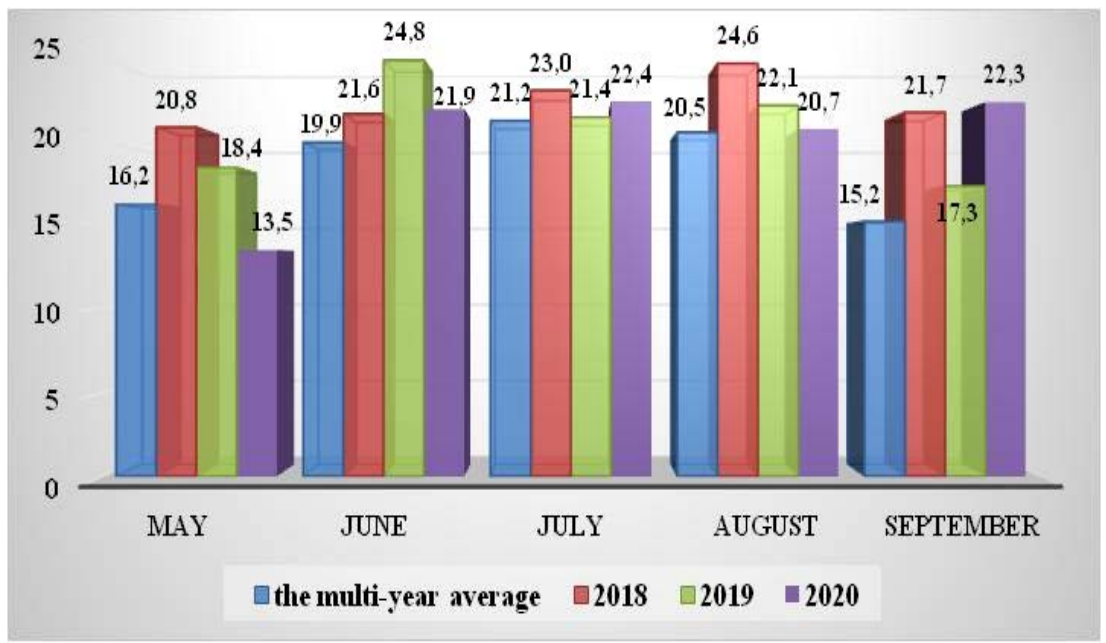

Figure 1. Dynamics of air temperature during the growing season of sunflower, 2018-2020

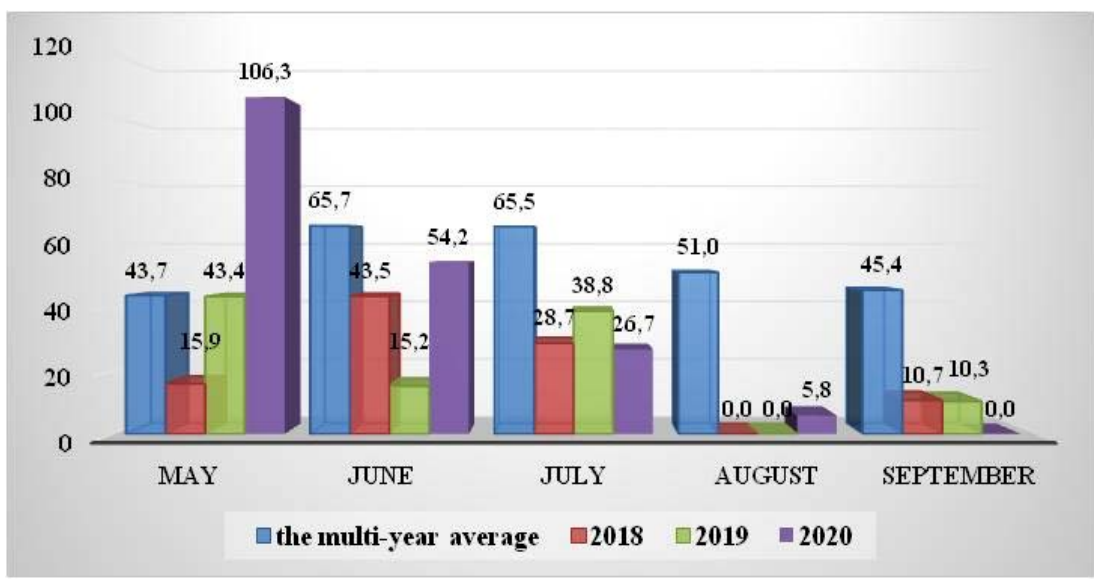

Figure 2. Dynamics of precipitation during the vegetation period of sunflower, 2018-2020 
August, as in the previous year of research, was extremely dry $(0 \mathrm{~mm})$ with no precipitation and average daily temperatures higher by $1.6^{\circ} \mathrm{C}$ than the average long-term data. Temperatures in September exceeded the longterm average by $2.1{ }^{\circ} \mathrm{C}$, and precipitation $(10.3 \mathrm{~mm})$ is $22.7 \%$ of the norm of long-term average for this month.

August was characterized by stable temperature regimes $\left(20.7^{\circ} \mathrm{C}\right)$, which did not differ from the average long-term data $\left(20.5^{\circ} \mathrm{C}\right)$, and an insignificant amount of precipitation $(5.8 \mathrm{~mm})$, which is only $11.4 \%$ of the norm $(51 \mathrm{~mm})$. In September, a record warm average daily air temperature $\left(22.3^{\circ} \mathrm{C}\right.$ ) was exceeded, which exceeded the norm by $7.1^{\circ} \mathrm{C}$ (average longterm $\left.15.2^{\circ} \mathrm{C}\right)$, and complete absence of precipitation $(0 \mathrm{~mm})$ at the norm of long-term average $45.4 \mathrm{~mm}$.

In 2020, there were conditions for sufficient moisture in the first months of sunflower development. May was characterized by an abnormally high amount of precipitation $(108.3 \mathrm{~mm})$, which exceeded the long-term average by almost 2.5 times $(147.8 \%)$. The average daily temperature in this month was lower by $2.7^{\circ} \mathrm{C}$ than the long-term average $\left(16.2^{\circ} \mathrm{C}\right)$. In June, there was a fall of $54.2 \mathrm{~mm}$ of precipitation, which was $82.5 \%$ of the norm $(65.7 \mathrm{~mm})$. The air temperature was $2.0^{\circ} \mathrm{C}\left(19.9^{\circ} \mathrm{C}\right)$ higher than the average long-term indicators. The amount of precipitation $(26.7 \mathrm{~mm})$ and the average daily temperature indicators $\left(22.4^{\circ} \mathrm{C}\right)$ in July are close to the indicators of the same period in 2018 (according to the long-term averages of $65.5 \mathrm{~mm}$ and $21.2^{\circ} \mathrm{C}$ ).

\section{Influence of PGR on productive characteristics of sunflower genotypes}

According to the data obtained from field research in the period 2018-2020, growth regulators had an individual character of action on the studied genotypes of sunflower. Thus, the influence of PGR depended on the genotype of the line and its origin, soil and climatic conditions at the time of PGR treatment and during the growing season, adaptability of the studied lines, experimental hybrids and varieties to adverse conditions and active substance PGR.

Growth encompasses the processes during which a plant forms its body, increasing its weight and body size. Like all other agricultural plants, sunflower grows and gives high yields only under favorable environmental conditions. Temperature, moisture, air and light are especially important for growth. Each plant grows normally at the optimum temperature. 
The introduction of plant growth regulators in agricultural practice is impossible without a deep and comprehensive study of their effect on the processes of metabolism, growth and development of the plant. This effect depends not only on the type of drug, but also on its dose, processing time, varietal characteristics of the culture and other factors. Yield is an integrated indicator, which reflects both the general conditions for all variants of the experiment, and the specific impact of individual agronomic measures. The data obtained are also necessary to understand the mechanisms of action of growth regulators.

In general, PGR Fulvital Plus, Ecostim and Quadrostim had a positive effect on plant productivity and 1000 seed weight of all sterile sunflower lines, except for the Skh1010A line, in which the productivity was lower when treated with Quadrostim $16.2 \mathrm{~g}$, compared with $17.0 \mathrm{~g}$ control and a simple sterile hybrid Skh808A $\times$ Kh1002V 48.8 g, compared with the control of $53.5 \mathrm{~g}$ on average over the years of research. Significant positive effect of PGR Ecostim and Quadrostim was observed in the line Skh808A with a productivity index of 65.6-66.4 $\mathrm{g}$, which is $13.5-14.9 \%$ higher than the control of $57.7 \mathrm{~g}$, weight of 1000 seeds $66.5-66.7 \mathrm{~g}$ (control $58.3 \mathrm{~g}$ ). The high level of dependence of the PGR influence on indicators and the dependence of the formation of one indicator on another in this line is confirmed by correlation-regression analysis $r=0.98-1(\mathrm{R} 2=0.96-1)$.

There was a significant effect of PGR Ecostim and Quadrostim on the mass of 1000 seeds in the line Skh1010A in the range of 59.4-60.1 $\mathrm{g}$ (control $51.8 \mathrm{~g}$ ) depending on the PGR used.

It should be noted positive increases in the studied indicators depending on the drug in the line Skh1002A (productivity 19.7-21.4 g), which is $27.1-38.1 \%$ higher than the control of $15.5 \mathrm{~g}$. The weight of 1000 seeds varied within 40, 0-47.1 $\mathrm{g}$ (control $37.8 \mathrm{~g}$ ).

In general, PGRs influenced the formation of productivity and increased it in the range of $0.7-38.1 \%$ compared to the control and depending on the PGR and the line. It should be noted that the greatest positive impact was achieved on the lines Skh808A and Skh1002A. These lines are characterized by high drought resistance and adaptability to adverse conditions in general and major diseases (Figure 3).

The effect of PGR on sunflower fertile lines was dependent on the genotype of the studied line. Thus, a significant effect on the basis of performance from 


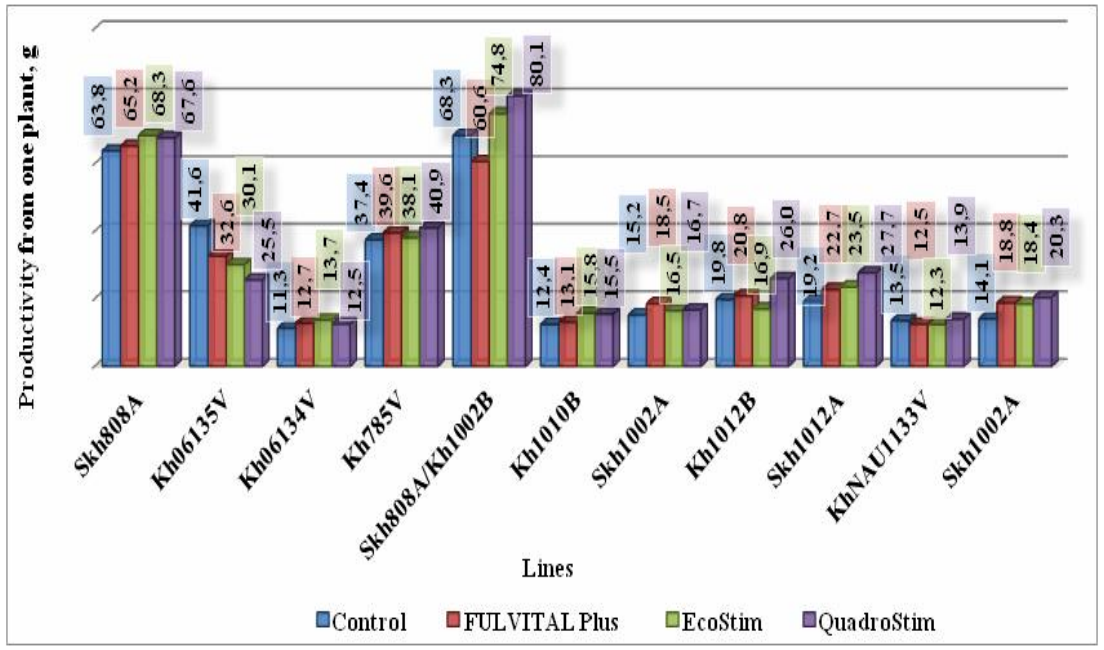

Figure 3. Influence of PGR on seed productivity from the basket of self-pollinating sunflower lines, 2018-2020

the basket was observed in the line Kh785V under the action of PGR Fulvital Plus $34.8 \mathrm{~g}$ (control $30.0 \mathrm{~g}$ ), which is $15.8 \%$ more than in the control and in the line Kh1012V when using Quadrostim 23.5 (control $18.9 \mathrm{~g}$ ), which is an increase of $24.7 \%$, respectively. It should be noted the genetic dependence on the influence of PGR Quadrostim line Kh1010A and its sterile analogue Skh1010A. Productivity from the basket decreased by $2.1-4.6 \%$ before the control in both cases, but at the same time the weight 1000 increased by $1.5-16 \%$, which is confirmed by the analysis of variance.

The studied PGR, depending on the genotype, had a positive effect on the trait weight of 1000 seeds. Thus, a significant increase over the years of research was observed in the line Kh06135V in the treatment of Fulvital Plus $53.1 \mathrm{~g}$ (control $46.1 \mathrm{~g}$ ), in the line $\mathrm{Kh} 785 \mathrm{~V}$ in the treatment of Ecostim and Quadrostim in the range of 51.9-52.4 g compared to the control 45, $8 \mathrm{~g}$. In the Kh1012V line, the increase in the mass of 1000 seeds by $16.0-30.3 \%$ occurred for all PGRs in comparison with the control (Figure 4).

Among the studied experimental hybrids, the use of PGR Fulvital Plus proved to be effective. On the basis of productivity from the basket, the increase was in the range of $4.3-17.4 \%$, respectively, according to the 


\section{Chapter «Agricultural sciences»}

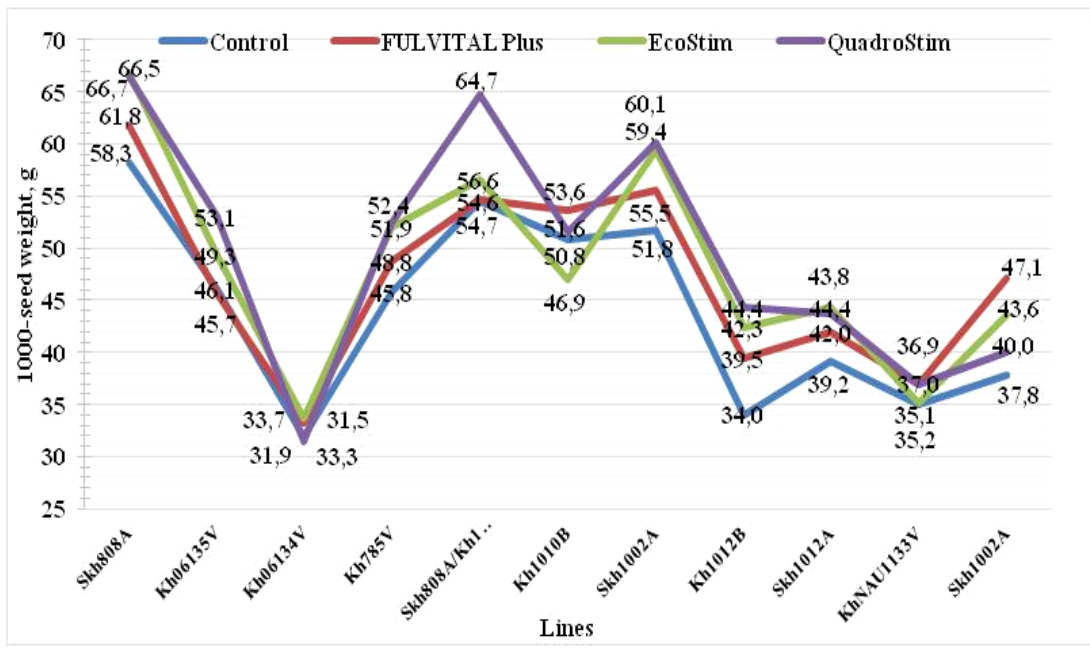

Figure 4. Influence of PGR on the mass of 1000 seeds of self-pollinating sunflower lines, 2018-2020

control and depending on the hybrid. The weight of 1000 seeds increased by $0.3-17 \%$ before control depending on the hybrid, and the nature of the seeds from $1.3 \%$ to $4.3 \%$.

Among the experimental sunflower hybrids studied, the effect of PGR Fulvital Plus and Ecostim on the trilinear hybrids Skh808A $\times$ Kh1002B $\times$ Kh06135V and Skh $808 \mathrm{~A} \times \mathrm{Kh} 1002 \mathrm{~B} \times \mathrm{Kh} 785 \mathrm{~V}$ was noticeable. The increase in productivity occurred in the range of $9.3-19.6 \%$, the weight of 1000 seeds from 0.3 to $14 \%$ depending on the PGR and the hybrid, respectively.

In a simple interlinear hybrid Skh1002A $\times$ Kh1012V, the weight of 1000 seeds increased under the action of Fulvital Plus to $57.8 \mathrm{~g}$ and Ecostim to $57.3 \mathrm{~g}$ (control $49.4 \mathrm{~g}$ ). The average productivity over the years increased and was in the range of 38.6-39.5 g per basket. The effect of PGR Ecostim in the hybrid Skh1012A $\times$ Kh06135V had a negative effect on the weight of 1000 seeds, which led to a decrease in its weight by an average of $18.2 \%$ compared to the control.

In the study of PGR on the sortoline hybrid Skh808AxShchelkunchik, only the use of Fulvital Plus was quite appropriate, as the improvement 
was on all grounds: productivity $73.5 \mathrm{~g}$ (control $63.5 \mathrm{~g}$ ) and weight of 1000 seeds $95.0 \mathrm{~g}$ (control $82.4 \mathrm{~g}$ ).

High rates of PGR impact on experimental hybrids can be justified by the presence of heterosis, which in turn increases the number of dominant alleles in the plant, which help plants better adapt to environmental conditions. As with the sterile and fertile lines described above, the effect of PGR has the best effect on the genotypes that are most adapted to environmental conditions.

PGR had almost no effect on the studied sunflower cultivars, except for the Lakomka cultivar, whose productivity varied between 82.4-50.9 $\mathrm{g}$ (control $75.9 \mathrm{~g}$ ). The weight of 1000 seeds was 106.3-108.1 when treated with Ecostim and Quadrostim (control $101.9 \mathrm{~g}$ ). In the Lyuks variety there was a decrease in productivity to $7.8 \%$ and the weight of 1000 seeds to $7.4 \%$ compared with the control on average over the years of research. The slight effect of PGR on sunflower varieties may explain their inconsistency in the onset of developed phases, the period of onset of a certain phase in the population can vary from a few days to a week. Given the fact that the period from mid-July to early September in the Forest-Steppe zone of Kharkiv region there is no or minimal rainfall in combination with high temperatures (Figure 5, 6).

\section{The effect of PGR on the oil content in sunflower seeds}

Seed oil is a trait that is controlled not only by the genotype of the plant, but also by environmental factors, such as rainfall, the sum of average temperatures, humidity during the growing season [32].

The use of PGR is one of the environmentally safe opportunities to increase the city of oil in sunflower seeds for the needs of the population. Thus, the use of PGR Fulvital Plus, Ecostim and Quadrostim depending on the genotype that was studied changed the percentage of oil in the seeds.

Effective was the use of PPR Fulvital Plus on the previously used experimental hybrids for the sleepyhead. According to the genotype, there is an increase in the size of the broth in the range of the lowest indicator in the line-varietal hybrid Skh808A $\times$ Shchelkunchik $(0.6 \%)$, up to the highest in the triline control in the hybrid Skh808A $\times$ Kh06135V up to 3 in hybrids Skh1002A $\times$ Kh1012B, Skh808A $\times$ Kh1002B $\times$ Kh785V and Skh1012A $\times$ Kh06135V, the adjustment in place of the other pid gave PGR varied between $1.1-2.6 \%$. 


\section{Chapter «Agricultural sciences»}

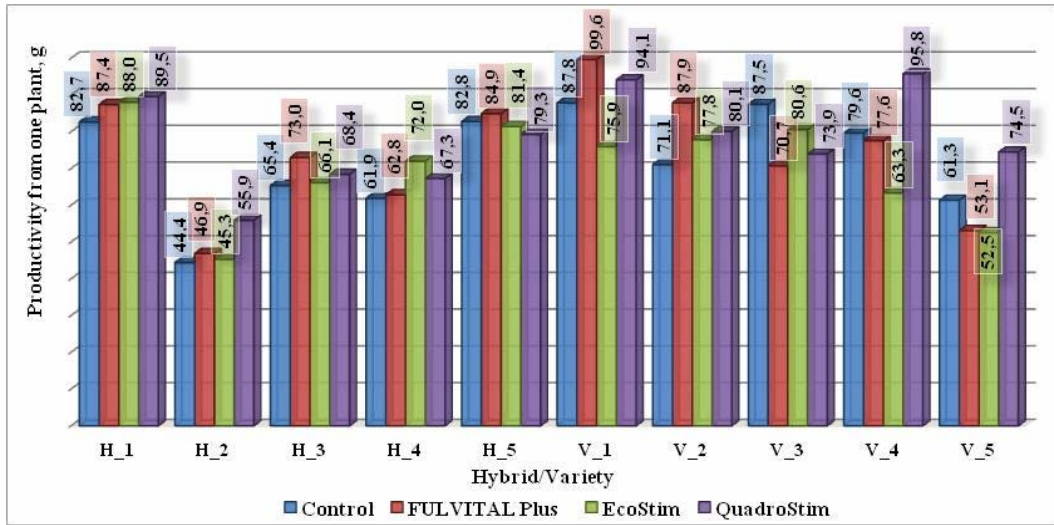

Figure 5. Influence of PGR on seed productivity from a basket of experimental hybrids and sunflower varieties, 2018-2020

(H 1. Skh808A $\times$ Kh1002B $\times$ Kh06135V; H 2. Skh1002A $\times$ Kh1012B; H 3.

Skh808A $\times$ Kh1002B $\times$ Kh785V; H 4. Skh1012A $\times$ Kh06135V;

H_5. Skh808A $\times$ Shchelkunchik; V_1. Shchelkunchik; V_2. Lakomka; V_3. Lyuks, V_4. Dons'kyy Krupnoplidnyy; V_4. Dons'kyy Krupnoplidnyy; V_5. Myr.)

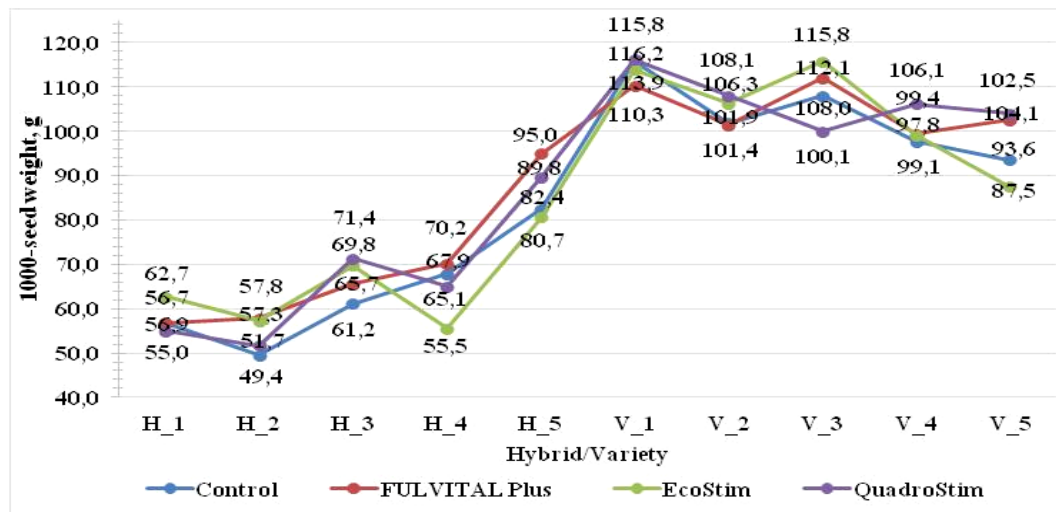

Figure 6. Influence of PGR on the mass of 1000 seeds of experimental hybrids and varieties of sunflower, 2018-2020

(H_1. Skh808A $\times$ Kh1002B $\times$ Kh06135V; H_2. Skh1002A $\times$ Kh1012B; H_3.

Skh $808 \mathrm{~A} \times \mathrm{Kh} 1002 \mathrm{~B} \times \mathrm{Kh} 785 \mathrm{~V} ; \mathrm{H}$ 4. Skh1012A $\times$ Kh06135V;

H_5. Skh808A $\times$ Shchelkunchyk; V_1. Shchelkunchyk; V_2. Lakomka;

V 3. Lyuks, V 4. Dons'kyy Krupnoplidnyy; V 5. Myr.) 
PGRs natural podrodzhennyam Ecostim significant effect on the indicator instead of olii not mav. For the victories of a simple intermediate hybrid Skh1002A $\times \mathrm{Kh} 1012 \mathrm{~V}$, there are a lot of changes in the world in the average for rock by $2.3 \%$.

The application was effective on experimental hybrids PGR Kvadrostim for a vignette of the line-varietal hybrid Skh808A $\times$ Shchelkunchik, instead of the number of variations in the rock control boundaries up to $50.8 \%$ (control 20.7\%). In the case of pre-juvenile experimental hybrids, an increase in the amount in the population in between $0.7-1.4 \%$ is attributable to the genotype and as before the control. In the sterile analogue of the simple midget hybrid Skh808A $\times$ Kh1002B, the increase in a large number of people in the world with the addition of PGR Kvadrostim in the average for rock became $1.7 \%$.

PGR studies had a significantly smaller effect on sunflower varieties than on the previously described experimental sunflower hybrids. Since the studied varieties of sunflower are a confectionery direction of use, the increase in the percentage of oil in the seeds is not very desirable.

In the Shchelkunchik variety, when the PGR is consumed, it has been replaced by the oil in the population in the middle for the rock change by $42.4-42.9 \%$, which is less than the control indicator by $1.2-1.6 \%$. In the variety Lyuks for rocky, on the strength of the PGR, it was seen that it increased in comparison with the average in today's market by 1.1-1.6\%. The varieties Lakomka, Donskiy Krupnoplidnyy and Myr, an indicator instead of the oil in the world, are fallow in the variety and PGR. In particular, there was a significant increase in oil content by $2.4 \%$ in the variety Donskiy Krupnoplidnyy pid infused PGR Ecostim $42.8 \%$ (control 40.3\%) (Table 1).

Injection of pre-existing PGR on the substitute of self-recording lines to sleepyheads is specific and varied in fallowness according to the genotype of line and PGR. It should be noted that, at the lines Skh808A, Kh06135V, Kh06134V, Kh785V and Kh1010B with the stagnation of PGR Fulvital Plus in the middle for rock changes instead of olii in today.

The amount of olii in the population varied in the borderlands by $0.4-1.2 \%$ less than before the control. The most effective inflow for the indicator of an increase in the amount of oil in the world at the line of closing the sterility of the file Kh1012B with the processing of PGR Quadrostim is $39.9 \%$, but 
Table 1

Influence of PGR on the oil content in the seeds of experimental hybrids and varieties of sunflower, the average for 2018-2019, \%

\begin{tabular}{|c|c|c|c|c|}
\hline Name & Kontrol & Fulvital Plyus & Ekostim & Kvadrostim \\
\hline \multicolumn{5}{|c|}{ Experimental hybrids } \\
\hline Significant at P $<0.05$ & 39,9 & 43,0 & 40,3 & 41,0 \\
\hline Skh1002A $\times$ Kh1012B & 45,7 & 48,3 & 48,0 & 46,9 \\
\hline Skh808A $\times$ Kh1002B $\times$ Kh785V & 47,0 & 48,1 & 47,8 & 48,4 \\
\hline Skh1012A $\times$ Kh06135V & 41,8 & 43,6 & 41,6 & 42,6 \\
\hline Skh808A $\times$ Shchelkunchik & 50,7 & 51,3 & 48,8 & 50,8 \\
\hline \multicolumn{5}{|c|}{ Sterile analogue of interlinear hybrid } \\
\hline Skh808A $\times$ Kh1002B & 48,9 & 48,3 & 47,1 & 50,6 \\
\hline \multicolumn{5}{|c|}{ Varieties } \\
\hline Shchelkunchik & 44,0 & 42,4 & 42,9 & 42,4 \\
\hline Lakomka & 45,7 & 46,6 & 45,7 & 45,1 \\
\hline Lyuks & 43,8 & 45,4 & 45,0 & 44,9 \\
\hline Donskiy Krupnoplidnyy & 40,3 & 40,0 & 42,8 & 39,6 \\
\hline Myr & 45,4 & 44,4 & 46,0 & 45,3 \\
\hline
\end{tabular}

Significant at $P<0.05$

$4.2 \%$ more than in the control $(35.7 \%)$. The growth of an increase in the amount of oil in the population was seen in the lines Skh1010A, Kh1012B and Skh1002A in the inter-areas of $1.5-2.8 \%$, according to the control when the PGR Ecostym was stagnant. In the case of a pre-determined line of admission in lieu of the disease caused by the presence of humic PGR Fulvital Plus in the boundaries of $35.4-36.3 \%$, which is $0.6-2.6 \%$ higher than the control (Table 2).

Among the pre-juvenile genotypes of self-filler lines, it means the sterile line Skh1010A and the line of closing the sterility file Kh1012B. In case of stagnation of pre-sluggish PGR, there is a change in the number of people in the world. Seemingly, the accumulation of oil in our life is directly related to the photosynthetic potential of the roslin for the accumulation of products for photosynthesis (assimilation), which is the basis for the establishment of lipids. The positive dynamics of the PGR consumption on these lines can characterize the greater adaptive capacity and adjustment in the case of PGR stagnation. 
Influence of PGR on the oil content in the seeds of self-pollinating sunflower lines, the average for 2018-2019, \%

\begin{tabular}{|c|c|c|c|c|}
\hline Name & Kontrol & Fulvital Plyus & Ekostim & Kvadrostim \\
\hline Skh808A & 51,3 & 50,2 & 51,0 & 51,4 \\
\hline Kh06135V & 39,0 & 37,8 & 38,5 & 39,9 \\
\hline Kh06134V & 43,6 & 43,2 & 43,9 & 43,9 \\
\hline Kh785V & 43,2 & 42,0 & 43,3 & 43,0 \\
\hline Kh1010B & 34,0 & 33,1 & 33,6 & 33,7 \\
\hline Skh1010A & 34,1 & 35,4 & 36,8 & 35,7 \\
\hline Kh1012B & 35,7 & 36,3 & 37,2 & 39,9 \\
\hline Skh1012A & 40,9 & 42,4 & 41,1 & 40,6 \\
\hline KhNAU1133V & 40,4 & 41,2 & 39,8 & 41,5 \\
\hline Skh1002A & 33,8 & 36,3 & 36,5 & 32,6 \\
\hline
\end{tabular}

Significant at $P<0.05$

\section{Conclusions}

In the researched article the theoretical generalization and the practical decision of questions concerning the characteristic of lines, varieties and hybrids of sunflower which consist in definition of laws of formation of productivity of plants under the influence of various PGR are resulted.

As a result of the research, different effects of PGR on lines, hybrids and varieties were established. It is noted that the lines Skh808A and Skh1002A have a greater potential to increase the structural indicators of the crop under the influence of PGR. One of the factors is their high adaptability to the environment. The average productivity increase from the basket under the influence of PGR was $5.1 \mathrm{~g}$ in the line Skh1002A, and in the line Skh808A by $7.1 \mathrm{~g}$. The weight of 1000 seeds increased from $0.3 \%$ to $24.7 \%$ depending on the PGR. The nature of the seeds varied and ranged from $3.7 \%$ to $17.3 \%$ depending on the drug and line.

The effect of PGR on fertile sunflower lines was smaller compared to sterile lines. An increase in productivity was observed in lines Kh785V by $15.8 \%$ and in Kh1012V by $27.7 \%$, respectively control. The main effect of PGR on these studied lines was observed in the increase in the mass of 1000 seeds. Thus, this indicator was in the line Kh1012 V - 44.4 g, which is 
$30.3 \%$ more than the control and in the line Kh06135V - 53.1 g, an increase of $15.3 \%$ to the control.

The use of PGR was quite effective in experimental hybrids. The increase in hybrid productivity was in the range of $0.3-19.6 \%$, the weight of 1000 seeds in the range of $3.4-16.7 \%$.

Among the quantitative features, the best performance indicators of PGR Fulvital Plus, Ecostim and Quadrostim on the line Skh808A were noted. Thus, the diameter of the basket increased and varied within $17.8-18.0 \mathrm{~cm}$ (control $17.2 \mathrm{~cm}$ ). In the Skh1002A line, the diameter of the basket averaged 14.1-15.3 cm over the years of research (control $13.8 \mathrm{~cm}$ ). Along with the increase in basket diameter, there was an increase in plant height in the range of 152-156 cm (control $150 \mathrm{~cm}$ ) depending on the PGR.

In the fertile line Kh785V, an increase in the diameter of the basket was observed during PGR processing in the range of 14.1-15.3 cm (control $13.8 \mathrm{~cm}$ ). Plant height increased according to PGR in the range of $152-156 \mathrm{~cm}$ (control $150 \mathrm{~cm}$ ).

Among the studied experimental hybrids, the effectiveness of PGR varied depending on the genotype of the plant. Thus, the best effect was observed in the linear varietal hybrid Skh $808 \mathrm{~A} \times$ Shchelkunchik, the diameter of the basket was 19.9-19.4 cm (control $17.2 \mathrm{~cm}$ ), the height index varied between 180-188 cm depending on the PGR (control $179 \mathrm{~cm}$ ).

The practical value of the work is determined by the importance of its final results, both for seed production, breeding practice and for production. The influence of the studied PGRs had an individual nature of influence and varied depending on the genotype of the line, growth regulator and weather conditions surrounding the plants at the time of treatment and subsequent vegetation.

During the research it was noted that PGR Fulvital Plus and Quadrostim had the greatest effect on the improvement of seed mass in the studied genotypes with an increase in the mass of 1000 seeds and the nature of the seeds. Fulvic acids contained in PGR Fulvital Plus increase the adaptive capacity of plants to adverse environmental conditions.

Plant growth regulators Ecostim and Quadrostim have proven to be effective in research as an effective way to increase the nature and weight of 1000 seeds of seed lines and experimental sunflower hybrids. 


\section{References:}

1. Kyrychenko V. V. (ed.). (2010). Special'na selekcija i nasinnyctvo pol'ovyh kul'tur: navch. posibnyk [Special breeding and seed production of field crops]. Kharkiv: PPI nd. a V. Ya. Yurieva NAAS Ukraine. (in Ukrainian)

2. Fedoryaka V. P., Bakhchivanzhi L. A., Pochkolina S. V. (2011). Efektyvnist' vyrobnyctva i realizacii' sonjashnyku v Ukrai'ni [Efficiency of production and sale of sunflower in Ukraine]. Socio-Economic Research Bulletin, vol. 41, no. 2, pp. 139-143. (in Ukrainian)

3. Yeshchenko I. V. (2014). Stan i problemy vyrobnyctva olijnyh kul'tur u Poltavs'kij oblasti [State and problems of oilseeds production in Poltava region]. Bulletin of the Poltava State Agrarian Academy, vol. 2, pp. 183-188. (in Ukrainian)

4. Ekonomichna statystyka / Ekonomichna dijal'nist' / Sil's'ke, lisove ta rybne gospodarstvo [Economic statistics / Economic activity / Agriculture, forestry and fisheries] (2020). State Statistics Service of Ukraine. Available from: http://www.ukrstat.gov.ua/ (accessed 2 February 2021). (in Ukrainian)

5. EC (2021). Short-term outlook for EU agricultural markets in 2021. European Commission. Brussels: DG Agriculture and Rural Development.

6. Eurostat. Rape, turnip rape, sunflower seeds and soya by area. Available from: https://ec.europa.eu/eurostat/databrowser/view/tag00100/default/bar?lang=en (accessed 5 April 2021).

7. UIPVE. (2020). Derzhavnyj rejestr sortiv roslyn, prydatnyh dlja poshyrennja v Ukrai'ni, $2020 \mathrm{r}$. [State Register of Plant Varieties Suitable for Distribution in Ukraine, 2020]. Kyiv: Ukrainian Institute of Plant Variety Examination. (in Ukrainian)

8. Rakul I. O., Ryabovol L. O. (2017). Stvorennja ta ocinka vyhidnyh materialiv dlja selekcii' gibrydiv sonjashnyku kondyters'kogo naprjamu vykorystannja [Creation and evaluation of source material for breeding confectionery sunflower hybrids directly use]. Collection of scientific papers of Uman National University of Horticulture, vol. 91, no. 1, pp. 236-243. (in Ukrainian)

9. Skoric D. (1989). Sunflower breeding. In: Polak, V. (ed.), Sunflower Monograph, Nolit, Beograd.

10. Derzhavnyj rejestr pestycydiv i agrohimikativ, dozvolenyh do vykorystannja v Ukrai'ni, 2020 [State Register of Pesticides and Agrochemicals Permitted for Use in Ukraine, 2020] [online]. Ministry of Ecology and Natural Resources of Ukraine. Available from: https://mepr.gov.ua/ (accessed November 17, 2020). (in Ukrainian)

11. Sendetsky V. M. (2018). Vplyv guminovyh preparativ na vrozhajnist' i jakisni pokaznyky nasinnja sonjashnyku v umovah Lisostepu Zahidnogo [Influence of humic preparations on yield and quality indices of sunflower seeds in the conditions of the Forest west of the West]. Scientific Bulletin of the National University of Life and Environmental Sciences of Ukraine. Series: Agronomy, vol. 294, pp. 32-41. (in Ukrainian)

12. Buryak Yu. I., Ogortsov Yu. E., Chernobab O. V., Klimenko I. I. (2014). Posivni jakosti nasinnja sonjashnyku zalezhno vid vplyvu reguljatoriv rostu roslyn ta protrujnykiv [Sowing qualities of sunflower seeds depending on the influence 
of plant growth regulators and seedlings]. Breeding and seed production, vol. 105, pp. 173-177. (in Ukrainian)

13. Pokoptseva L. A., Eremenko O. A., Bulgakov D. V. (2015). Vykorystannja reguljatoriv rostu roslyn dlja peredposivnoi' obrobky nasinnja sonjashnyku gibrydu Armada [The use of plant growth regulators for pre-sowing treatment of sunflower seeds of Armada hybrid]. Herald of agrarian science of Black sea region, no. 4, pp. 127-135. (in Ukrainian)

14. Tsigankova V. A., Andrusevich Y. V., Babayants O. V., Ponomarenko S. P., Medkov A. I., Galkin A. P. (2013). Pidvyshhennja reguljatoramy rostu imunitetu roslyn do patogennyh grybiv, shkidnykiv i nematode [Increasing growth regulators of plant immunity to pathogenic fungi, pests and nematodes]. Physiology and biochemistry of cultivated plants, vol. 45, no. 2, pp. 138-147. (in Ukrainian)

15. Proposition. Reguljatory rosta dlja rastenyj, vlyjanye reguljatorov rosta na rastenyja [Growth regulators for plants, the effect of growth regulators on plants]. Available from: https://propozitsiya.com/zernovye-kultury-i-regulyatory-rosta (accessed 2020 November 17). (in Russian)

16. Chuiko D. V. (2020). Produktyvnist' i elementy formuvannja struktury urozhaju genotypiv sonjashnyku pry obrobci reguljatoramy rostu roslyn [Productivity and elements of the formation of the structure of the yield of sunflower genotypes when treated with plant growth regulators]. Bulletin of Kharkiv National Agrarian University named after V.V. Dokychaiev. The series "Crop production, selection and seed production, fruit and vegetable growing, vol. 1, no. 2, pp. 114-128. (in Ukrainian)

17. Chuiko D. V., Bragin O. M., Mykhailenko V. O., Romanova T. A., Romanov O. V. (2020). Vplyv reguljatoriv rostu roslyn na produktyvnist' linij sonjashnyku [Effects of plant growth regulators on the performance of sunflower lines. Breeding and seed production]. Breeding and seed production, vol. 117, pp. 215-226. (in Ukrainian)

18. Bragg, P. L., Rubino, P., Henderson, F. K. G., Fielding, W. J., \& Cannell, R. Q. (1984). A comparison of the root and shoot growth of winter barley and winter wheat, and the effect of an early application of chlormequat. The Journal of Agricultural Science, no. 103(2), pp. 257-264.

19. Adams, R., Kerber, E., Pfister, K., \& Weiler, E. W. (1992). Studies on the action of the new growth retardant CGA 163'935 (cimectacarb). Proceedings of the In Progress in plant growth regulation, Springer, Dordrecht, pp. 818-827.

20. Buryak Yu. I., Ogortsov Yu. E., Chernobab O. V., Klimenko I. I. (2014). Efektyvnist' zastosuvannja reguljatoriv rostu roslyn ta mikrodobryva v nasinnyctvi sonjashnyku [The effectiveness of plant growth regulators and microfertilizers in sunflower seed production]. Bulletin of the Center for scientific support APV Kharkiv region, vol. 16, pp. 20-25. (in Ukrainian)

21. Marenich M. M., Yurchenko S. O., Bagan A. V., Yeshchenko V. M. (2018). Formuvannja produktyvnosti sortiv pshenyci ozymoi' pid dijeju guminovyh rechovyn [Formation of productivity of winter wheat varieties under the action of humic substances]. Bulletin of the Poltava State Agrarian Academy, no. 1, pp. 63-66. https://doi.org/10.31210/visnyk2018.01.09 (in Ukrainian) 
22. Knapowski, T., Szczepanek, M., Wilczewski, E., \& Pobereżny, J. (2015). Response of Wheat to Seed Dressing with Humus and Fo liar Potassium Fertilization. Journal of agricultural science and technology, 17(6): 1559-1569.

23. Ousley, M. A., Lynch, J. M., \& Whipps, J. M. (1994). Potential of Trichoderma spp. as consistent plant growth stimulators. Biology and Fertility of Soils, 17(2), 85-90. https://doi.org/10.1007/BF00337738

24. Lucy, M., Reed, E., \& Glick, B.R. (2004). Applications of free living plant growth-promoting rhizobacteria. Antonie van leeuwenhoek, 86(1), 1-25.

25. Glick, B. R., \& Bashan, Y. (1997). Genetic manipulation of plant growth-promoting bacteria to enhance biocontrol of phytopathogens. Biotechnology advances, 15(2): 353-378. https://doi.org/10.1016/S0734-9750(97)00004-9

26. Sendetsky V. M. (2017). Vplyv reguljatoriv rostu na vrozhajnist' sonjashnyku za vyroshhuvannja v umovah Lisostepu Zahidnogo [Influence of growth regulators on sunflower yield during cultivation in Western Forest-Steppe conditions]. Scientific Bulletin of the National University of Life and Environmental Sciences of Ukraine. Series: Agronomy, vol. 269, pp. 53-61. (in Ukrainian)

27. Gorash O. S., Sendetsky V. M. (2018). Optymizacija produkcijnogo procesu agrocenozu sonjashnyku za vykorystannja reguljatoriv rostu [Optimization of the production process of sunflower agrocenosis with the use of growth regulators]. Scientific reports of NULES of Ukraine, vol. 5, no. 75, pp. 1-14. (in Ukrainian)

28. Chuiko D. V., Bragin A. N. (2019). Vlijanie reguljatorov rosta na sinhronizaciju cvetenija semennyh posevov podsolnechnika [The influence of growth regulators on the synchronization of flowering of seed crops of sunflower]. «Research and Publishing Center «Actuality. RF»»), no. 5, pp. 5-6. (in Russian)

29. Tkalich Ju. I., Nicenko M. P. (2014). Osoblyvosti fotosyntetychnoi' dijal'nosti gibrydiv sonjashnyku zalezhno vid biopreparativ [Features of photosynthetic activity of sunflower hybrids depending on biological products]. Visnyk Dnipropetrovskogo Derzhavnogo Agrarnoekonomichnogo Universytetu, no. 2, pp. 124-130. (in Ukrainian)

30. Dospekhov B. A. (1985). Metodika opytnogo dela [Methods of field experience]. Moscow: Agropromizdat. (in Russian)

31. Hoptsii T. I. (2003). Genetyko-statystychni metody v selekcii' [Genetic and statistical methods in breeding]. Kharkiv: KhNAU nd. a V. V. Dokuchaev. (in Ukrainian)

32. Petibskaya V. S. (1993). Vlijanie meteorologicheskih uslovij na kachestvo masla podsolnechnika [Influence of meteorological conditions on the sunflower oil quality]. Izvestiya Vysshykh Uchebnykh Zavedeniy. Pishchevaya Tekhnologiya, vol. 1, no. 2, pp. 32-34. (in Russian) 